\title{
ADAPTATION OF THE NEYMAN-PEARSON CRITERIA FOR ASSESSING THE RELIABILITY OF THE CHOICE OF THE METHOD FOR DETERMINING THE COEFFICIENTS OF THE MATHEMATICAL MODEL OF LOW-INTENSITY ELECTRORETINOSIGNAL
}

\author{
Pavlo Tymkiv
}

\section{Ternopil Ivan Puluj National Technical University, Ternopil, Ukraine}

\begin{abstract}
Summary. With a decrease in the intensity of light irritation to detect the risk of neurotoxicity, they receive a low-intensity electroretinosignal, which needs to be further elaborated. In works by Tkachuk $R$ A. and Yavorskyy B. I. the application of the Kalman filter and the method for determining the coefficients of the mathematical model of the electroretinosignal is proposed. However, the method of direct directed search (search) of coefficients is used, which has considerable time complexity, which makes it impossible to automate the application and reconfiguration of the Kalman filter for the processing of low-intensity electroretinosignal. Known works, in which the method of determining the coefficients of the mathematical model of low-intensity electroretinosignal has been improved by checking in several iterations with the change of the pitch step. Therefore, in order to evaluate the proposed advanced method, it is necessary to conduct a statistical test of choice. The problem of choosing the method for determining the coefficients of the mathematical model of low-intensity electroretinosignal is solved by methods of statistical choice theory. Validation of reliability is based on the Bayesian concept of probability theory, on the basis of which the Neyman-Pearson criteria is chosen and adapted to the task of selecting (approving) the solution. The reliability of the choice of the method for finding the coefficients was determined with a fixed probability of a false choice of the method (0,1; 0,01; 0,001 and 0,0001).

Key words: electroretinography, electroretinosignal, low-intensity electroretinosignal, mathematical model, Kalman filter, Neyman-Pearson criteria.
\end{abstract}

Statement of the problem. The modified electroretinography investigation of human body is used in evaluating the neurotoxicity risk [1], but at the same time it is necessary to ensure high resolution and accuracy of the resulting low-intensity electroretinosignal processing (ERS). The investigation of low-intensity ERS is associated with the problem of detecting the small useful signal in the noisy signal mixture [2-4]. The given problem in ophthalmological diagnostic systems (particularly in CALYPSO, DKZO-01 systems and others) is solved by averaging the certain $(\mathrm{N})$ number of mixtures registrations, resulting in decrease of noise dispersion in $\sqrt{N}$ times, and with the increase of registrations numbers the value of the average signal-noise mixture is directed to ERS values.

However, this processing method is associated with patient inconveniences and tiredness and for low-intensity ERS the $\mathrm{N}$ number can amount to dozens of registrations, that is not always possible.

Analysis of the available investigation results. In papers by Tkachuk R. A. and Yavorskyy B. I. [5, 6] on the heuristic basis the use of Kalman filter is substantiated and the method of successive selection of the coefficients for the calculated recursive structure of the 2nd order as the mathematical model of the standard previously generated electroretinogram (ERG) based on the mean-square criterion is used to ensure the necessary accuracy of useful ERS reproduction. 
The method of successive selection of coefficients (straight directed selection hereinafter referred to as prototype method) of the mathematical model is used in [5,6]. The method (hereinafter referred to as the improved method) for the determination these coefficients by straight directed selection in several iterations with the selection step change is proposed in [7-9].

The objective of the paper is to determine the reliability of the method choice for defining the coefficients of the low-intensity ERS mathematical model while processing the Kalman filter.

Statement of the problem. The low-intensity ERS selected from the bioobject can be considered as the mixture of useful electroretinosignal and noise:

$$
x(i \Delta t)=s(i \Delta t)+n(i \Delta t)
$$

where $s_{(i \Delta t)}$ is useful low-intensity ERG, $n(i \Delta t)$ is noise, $\Delta t$ is sampling step ( $\Delta t=1 / 2 f, f$ is lowintensity ERS sampling frequency in case of Kotelnikov theorem), $i$ is the sample number. While evaluating the prototype method and the improved method, let us carry out the statistical test and compare the validity of the work results. Validity evaluation is performed on the basis of Bayesian concept of probability theory, due to which the criterion for the choice (approval) solution substantiation is constructed.

Under the initial hypothesis $H_{0}$ (zero-hypothesis) we mean the acceptance of the prototype method, and under the alternative hypothesis $H_{l}$ we mean the adoption of the improved method.

That is, on the basis of the Bayesian concept of probability theory:

$$
P(B) P(C \mid B)=P(C) P(B \mid C)
$$

where $P(B)$ is the probability of the prototype method test result, $P(C)$ is the probability of the improved method test result, $P(C \mid B)$ is the conditional probability of improved method while actually it is the prototype method, $P(B \mid C)$ is the conditional probability of the prototype method selection while actually it is improved method.

By analogy with the known interpretations of conditional probabilities let us introduce the following notions: $P(B \mid C)$ - an error of the first kind, $P(C \mid B)$ - an error of the second kind.

Since the a priori probabilities of these errors are unknown, we will use the NeumannPearson criterion which maximizes the probability of selecting more reliable algorithm $\left(P_{d}\right)$ with predetermined value of the probability of the false choice of less reliable algorithm $\left(P_{f a}\right)$.

Also the probability of the false choice of the less reliable $P_{f a}$ algorithm allows us to record the negative effects or losses while making wrong decision.

Results of the investigation. By means of simulation modeling we obtain statistics of low-intensity ERS $x(t)$ with normal probability distribution (Fig. 1).

Let us apply them in order to obtain the test statistics of Kalman filter operation, whose coefficients are calculated by the prototype method and the improved method. 


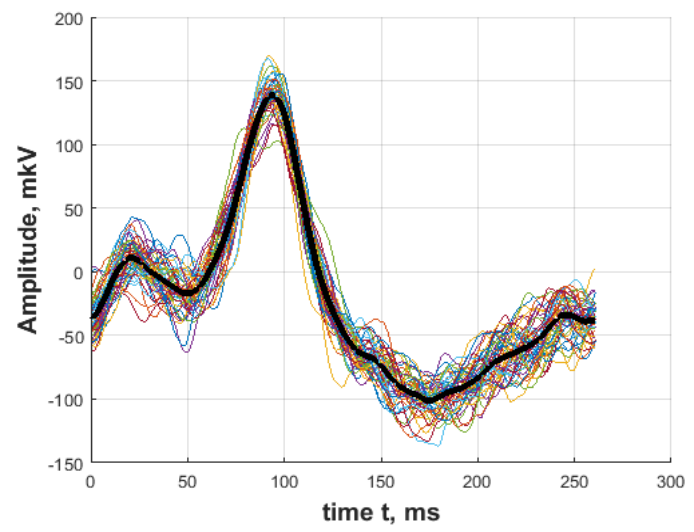

a)

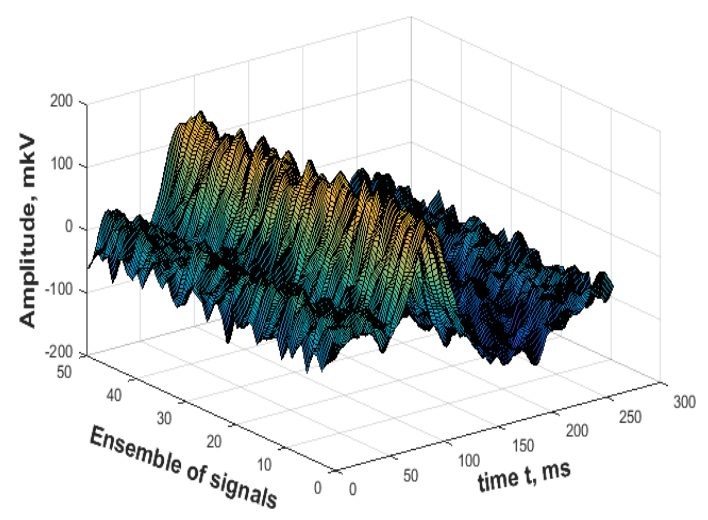

b)

Figure 1. Ensemble of simulation-modeled low-intensity ERS: a) - ensemble of simulated low-intensity ERS by prototype method, b) - ensemble of simulated low-intensity ERS by advanced method

The distribution densities of the probability of mean square error (MSE) modeling as the accuracy evaluation of the method for determination of the coefficients of the low-intensity ERS mathematical model, obtained test statistics, are shown in Fig. 2.

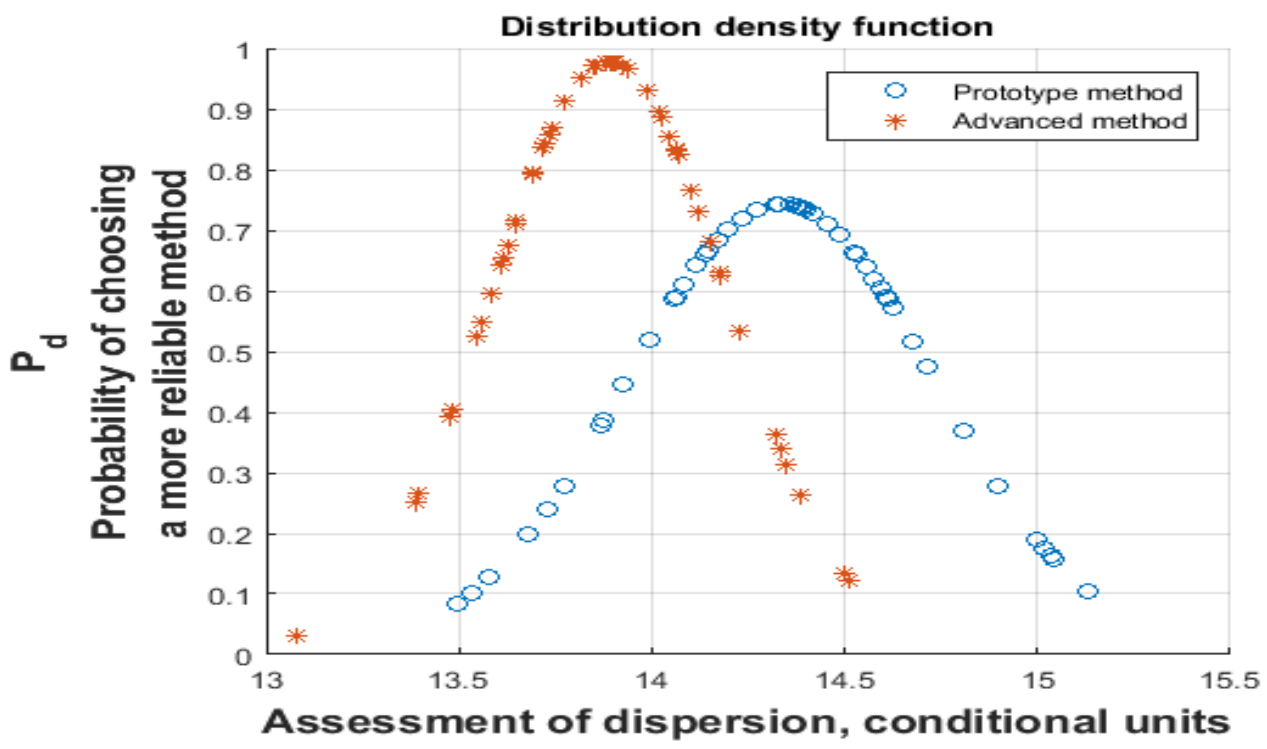

Figure 2. The function of the distribution density of the MSE of the prototype method and the improved method

The task of selecting the method for determination of the coefficients of the lowintensity ERS mathematical model during processing by Kalman filter is solved by methods of decision-making statistical theory [10].

While selecting the method for determination of the coefficients of Kalman mathematical model, there are two groups of events.

The first group consists of two events reflecting hypothesis in the observed sequence: «selection of the improved method» (hypothesis $H_{l}$ ) with probability $P\left(H_{l}\right)$ and «selection of the prototype method» (hypothesis $\left.H_{0}\right)$ with the probability $P\left(H_{0}\right)$. These hypotheses are incompatible and form the complete group $P\left(H_{1}\right)+P\left(H_{0}\right)=1$, since only one of them can occur at the given moment. 
The second group includes two other events that reflect the actual situation after analyzing the low-intensity ERS simulation by the coefficients determined by the prototype method and the improved method and decision making: «selection of the improved method» (event $A_{1}$ ) and «selection of the prototype method» (event $A_{0}$ ). The probability of these events occurrence is: $P\left(A_{1}\right)$ and $P\left(A_{0}\right)$. These events are incompatible and form the complete group: $P\left(A_{1}\right)+P\left(A_{0}\right)=1$.

In the process of observation in each implementation one of the events from the first group and one of the events from the second group take place. As a result, for each implementation, one of four options of the simultaneous onset of two dependent events occurs.

Two of these options will give the faultless solution: $H_{1}$ and $A_{1}-$ selection of the improved method at greater speed and $H_{0}$ and $A_{0}$ - selection of the prototype method with higher accuracy. And two options will give false solutions: $H_{1}$ and $A_{0}-$ the false selection of the improved method and $H_{0}$ i $A_{1}$ - the false selection of the prototype method.

The above stated problem of selecting the methods for determination of the lowintensity ERS coefficients for Kalman filter is a partial case of the general problem for hypotheses statistical testing. In this case, it is necessary to decide which event occurred, i.e. which of the hypotheses is correct.

The expediency of the criterion application is determined by the nature of the choice problem and the a priori probabilities $p\left(H_{1}\right)$ i $p\left(H_{0}\right)=1-p\left(H_{1}\right)$ known or unknown data.

The conditional probability of the false $P_{f a}$ determination is interpreted as the probability that the value of the test statistic $q(t)$ exceeds some limiting value of the threshold $\gamma$, leading to the false solution.

The probability $P_{f a}$ is determined by the following expression:

$$
P_{f a}=P\left(A_{1} \mid H_{0}\right)=P[q(t) \geq \gamma]=\int_{\gamma}^{\infty} W_{0}(q) d q
$$

The probabilistic probability of the false choice, that is, the probability that the value of the test statistic $q$ does not exceed the level $\gamma$ is:

$$
P\left(A_{0} \mid H_{1}\right)=P[q(t) \leq \gamma]=\int_{0}^{\gamma} W_{1}(q) d q
$$

The probability of accepting one of two false solutions in accordance with the rule of adding probabilities is:

$$
\begin{aligned}
& P\left[\left(H_{0} \cap A_{1}\right) \text { або }\left(H_{1} \cap A_{0}\right)\right]=P\left(H_{0} \cap A_{1}\right)+P\left(H_{1} \cap A_{0}\right)= \\
& =P\left(H_{0}\right) \int_{\gamma}^{\infty} W_{0}(q) d q+P\left(H_{1}\right) \int_{0}^{\gamma} W_{1}(q) d q .
\end{aligned}
$$

The probability of the correct $P_{d}$ method selection is interpreted as the probability that the value of the test statistic $q$ exceeds some limiting value of the threshold $\gamma$, and correct decision about the method selection will be made.

The probability $P_{d}$ is defined by the following expression: 


$$
\begin{aligned}
& P_{d}=P\left[\left(H_{0} \cap A_{0}\right) \text { або }\left(H_{1} \cap A_{1}\right)\right]=1-P\left[\left(H_{0} \cap A_{1}\right) \text { або }\left(H_{1} \cap A_{0}\right)\right]= \\
& =P\left(H_{0}\right) \int_{0}^{\gamma} W_{0}(q) d q+P\left(H_{1}\right) \int_{\gamma}^{\infty} W_{1}(q) d q .
\end{aligned}
$$

In order to find the optimal threshold level $\gamma$ it is necessary to determine its value, in which the probability of the correct solution will be maximal. As a result, we get:

$$
\frac{W_{1}(h)}{W_{0}(h)}=\frac{P\left(H_{0}\right)}{P\left(H_{1}\right)}
$$

Let us interpret Fig. 2, for adaptation of binary classification of two signals, and in our case two methods. The given MSE probability distribution densities with the application of the prototype method $W_{0}(q)$ and the improved method $W_{l}(q)$ correspond to the normal distribution law. From Fig. 2 it is evident that the threshold $\gamma$ level is increased with MSE dispersion increase. At $P\left(H_{0}\right)=P\left(H_{1}\right)=0,5$ the optimal threshold level is determined by the intersection point of the distribution functions $W_{0}(q)$ i $W_{1}(q)$.

To make a decision on selection of the improved method, it is necessary that:

$$
\frac{W_{1}(q)}{W_{0}(q)} \geq \frac{P\left(H_{0}\right)}{P\left(H_{1}\right)}
$$

If:

$$
\frac{W_{1}(q)}{W_{0}(q)}<\frac{P\left(H_{0}\right)}{P\left(H_{1}\right)}
$$

then a decision is taken about the selection of the prototype method.

Let's analyze the known criteria for choosing the optimal to the set task for selection of the coefficients determination method:

determination method are set:

1. At $P\left(H_{0}\right)=P\left(H_{1}\right)=0,5$ we obtain the statistical criterion - the criterion of the ideal observer, which is the simplest one. Its main disadvantage is the need to know the a priori probabilities of $P\left(H_{1}\right)$ presence or the $P\left(H_{0}\right)$. In addition, the criterion of the ideal observer does not take into account the consequences of false decisions.

2. To eliminate this disadvantage in the equation for estimation the probability of the false solution the weight coefficients $B$ and $C$, characterizing the losses connected with the false selection of the coefficients

$$
\mathrm{P}\left[\left(\mathrm{H}_{0} \cap \mathrm{A}_{1}\right) \text { or }\left(\mathrm{H}_{1} \cap \mathrm{A}_{0}\right)\right]=\mathrm{B} \cdot \mathrm{P}\left(\mathrm{H}_{0} \cap \mathrm{A}_{1}\right)+\mathrm{C} \cdot \mathrm{P}\left(\mathrm{H}_{1} \cap \mathrm{A}_{0}\right)
$$

In this case, the decision of the method selection is made while performing inequality:

$$
\frac{W_{1}\left(q_{1}, q_{2}, q_{3}, \ldots q_{N}\right)}{W_{0}\left(q_{1}, q_{2}, q_{3}, \ldots q_{N}\right)} \geq \frac{B \cdot P\left(H_{0}\right)}{C \cdot P\left(H_{1}\right)}
$$


This statistical criterion is called the criterion of minimal risk. Its application is difficult for the task of method selection not only due to the lack of a priori probabilities $P\left(H_{1}\right)$ and $P\left(H_{0}\right)$, but also because of the lack of a priori estimates of the importance of weight coefficients $B$ and $C$.

3. Another common criterion is the criterion of maximum likelihood. The above mentioned distribution function $W\left(q_{1}, q_{2}, q_{3}, \ldots q_{N}\right)$ is called the likelihood function, the maximal likelihood method is based on it and the maximum probabilistic estimation of MSE methods with the least (relative to other methods) dispersion value is determined by this method. While using the criterion of maximum likelihood, the solution concerning the method selection is made in the case when the likelihood function $W_{l}$ exceeds the likelihood function $W_{0}$ :

$$
\frac{W_{1}\left(q_{1}, q_{2}, q_{3}, \ldots q_{N}\right)}{W_{0}\left(q_{1}, q_{2}, q_{3}, \ldots q_{N}\right)} \geq 1
$$

4. As we have already indicated, the a priori probabilities necessary to make a decision concerning the method selection during its processing are unknown. Therefore, one more criterion, which does not depend on these probabilities, is most widely used. This is the Neumann-Pearson criterion, which ensures the maximum probability of the correct determination $P\left(H_{1} \cap H^{\prime}{ }_{1}\right)$ (hereinafter referred to as $\left.P_{d}\right)$ with the given probability of false determination $P\left(H_{0} \cap H^{\prime}{ }_{1}\right)$ (hereinafter referred to as $\left.P_{f a}\right)$.

In accordance with this criterion, the threshold value $\gamma$ is chosen from the given conditional probability of the false definition:

$$
P[q(t) \geq h]=\int_{\gamma}^{\infty} W_{0}(q) d q
$$

Thus, the solution to the method determination task is to calculate the likelihood ratio:

$$
L=\frac{W_{1}\left(q_{1}, q_{2}, q_{3}, \ldots q_{N}\right)}{W_{0}\left(q_{1}, q_{2}, q_{3}, \ldots q_{N}\right)}
$$

The decision concerning the method selection is made in the case when the likelihood ratio exceeds a certain fixed level $\gamma$, established in advance, depending on the accepted criterion.

According to the Neumann-Pearson criterion, the probability of the false choice of $P_{f a}$ method should be specified as follows [10]:

$$
P_{f a}=\int_{\gamma}^{\infty} W_{0}(q) d q=1-\Phi\left(\frac{h-m_{0}}{\sqrt{D_{0}}}\right)
$$

where $\Phi(x)=\frac{1}{\sqrt{2 \pi}} \int_{-\infty}^{x} e^{\frac{-u^{2}}{2}} d u$ is the probability integral.

Then the probability of the correct method selection is: 


$$
P_{d}=\int_{\gamma}^{\infty} W_{1}(q) d q=1-\Phi\left(\frac{h-m_{1}}{\sqrt{D_{1}}}\right)
$$

From expression (15), according to the given probability of the false choice of $P_{f a}$ method, the level $\gamma$ is definitely determined, and knowing it, we find the probability of the correct choice of $P_{d}$ method.

$$
\gamma=\sqrt{D_{0}} \Phi^{-1}\left(1-P_{f a}\right)+m_{0}
$$

Characteristics of the method selection reliability for determining the coefficients is the dependence of the probability of correct $P_{d}$ determination from the deviation coefficient [10], at the fixed probability of the false choice of $P_{f .}\left(P_{f a}=0,1 ; P_{f a}=0,01 ; P_{f a}=0,001 ; P_{f a}=0,0001\right)$ method. The corresponding graphs are shown in Fig. 3 and Fig. 4

On the other hand, according to [10], the problem of detecting the constant signal (in our case, the problem of distinguishing the selection of two methods) can be generalized and considered as the problem of distinguishing two constant signals in the presence of Gaussian noise. This problem is called the mean-shifted Gauss-Gauss problem. In this case, in general, we get the following instead of statistics:

$$
T^{\prime}\left(X_{N}\right) \sim \begin{cases}N\left(0, \sigma^{2} / N\right) n p u & H_{0} \\ N\left(A, \sigma^{2} / N\right) n p u & H_{1}\end{cases}
$$

We derive:

$$
T\left(X_{N}\right) \sim \begin{cases}N\left(\mu_{0}, \sigma^{2}\right) n p u & H_{0} \\ N\left(\mu_{1}, \sigma^{2}\right) n p u & H_{1}\end{cases}
$$

The hypothesis $H_{1}$, if $T>\gamma$, and $H_{0}$ is accepted in other case. Thus, one or another hypothesis is accepted depending on the mean-shifted statistic value. For such determinant we will define the deviation factor $\left(K_{\text {deviation }}\right)[10]$ by the formula:

$$
K_{\text {deviation }}=\frac{\left(\mu_{1}-\mu_{0}\right)^{2}}{\sigma_{1}^{2}}
$$

Let us determine the deviation factor $\left(K_{\text {deviation }}\right)$ for the test statistics of MSE distribution by the prototype method and the improved method (Fig. 3). 


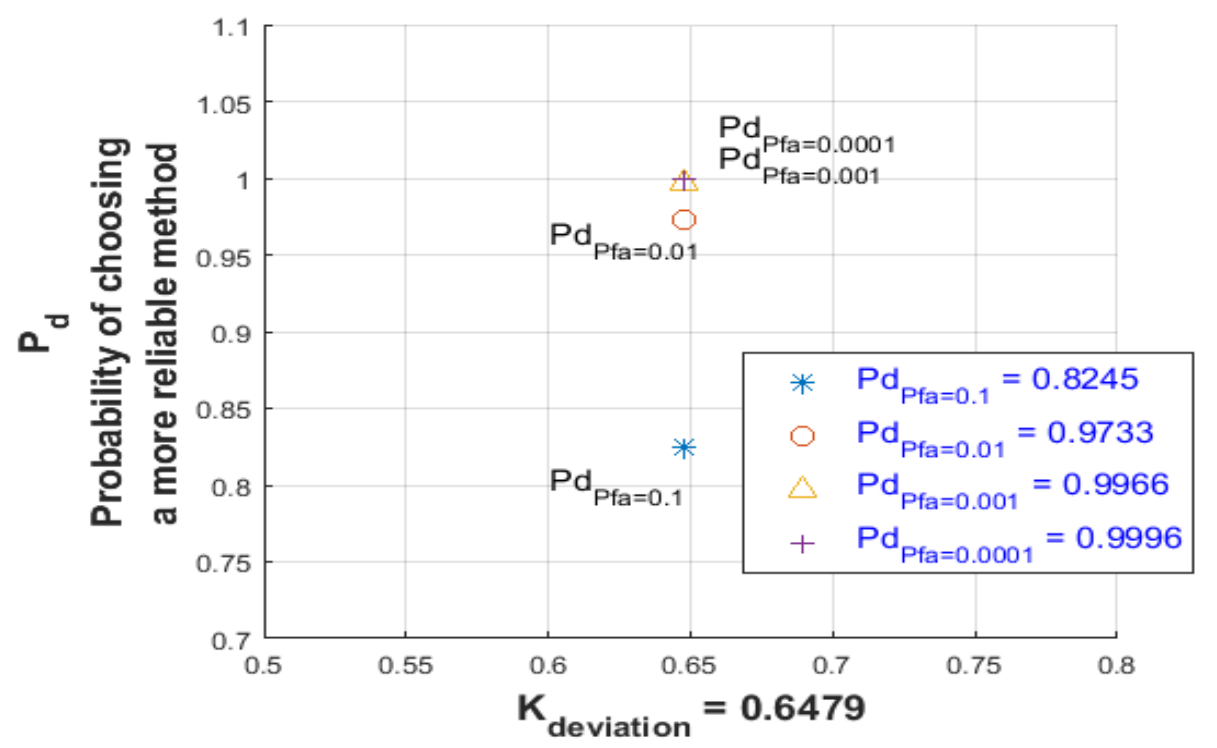

Figure 3. Definition probability of choosing a more reliable method $\left(P_{d}\right)$ in Fig. 4.

The dependence of the selection probability on the deviation factor $\left(K_{\text {deviation }}\right)$ is shown

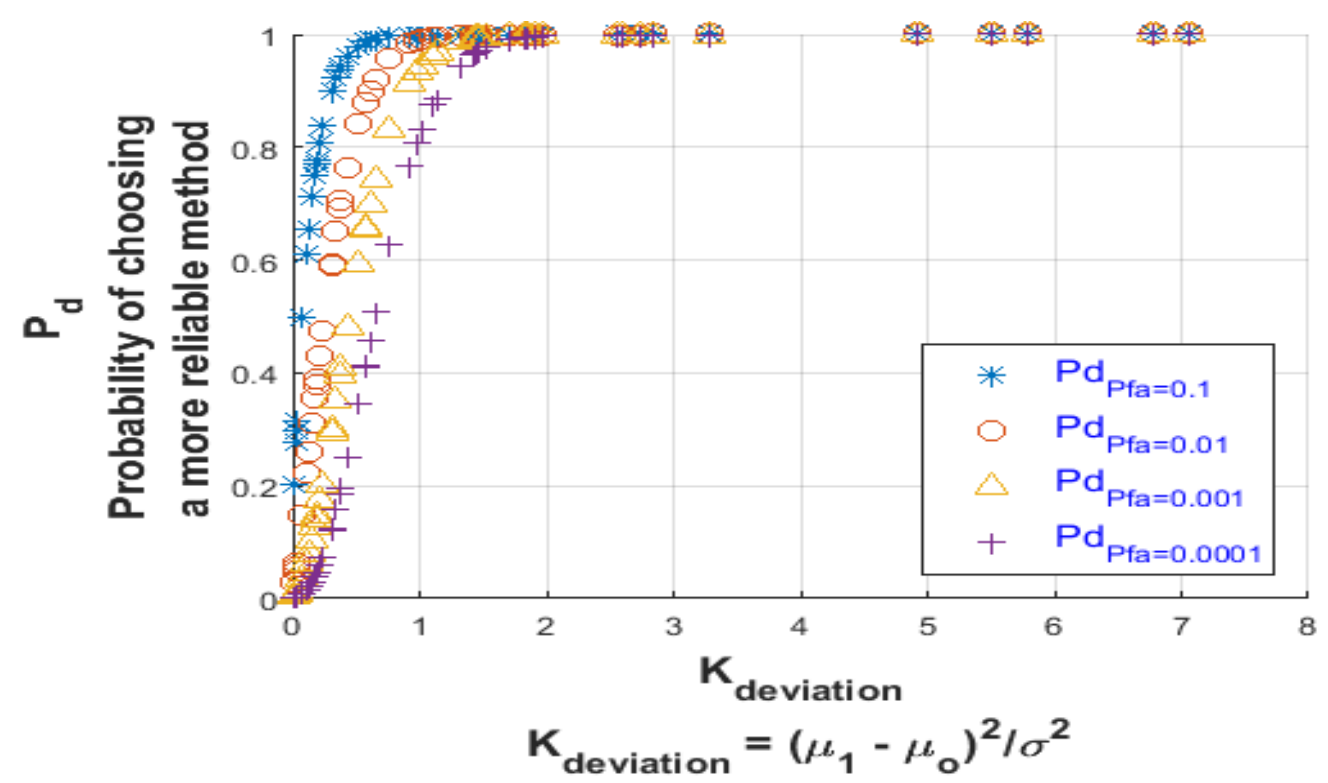

Figure 4. Functional dependence of the probability of choosing a method from the $K_{\text {deviation }}$

Based on the results of the binary classification of the adapted Neyman-Pearson criteria and the calculated probability values of the correct choice of $P_{d}$ method while determining the probability of $P_{f a}$ false choice, it is necessary in further investigation to determine the dependence of the number of correctly classified positive results on the number of incorrectly classified false results using ROC analysis.

Conclusions. In order to compare the reliability of method selection for determining the low-intensity ERS mathematical model coefficients, the statistical test of two methods: the prototype method and the improved method was carried out. 
Evaluation of reliability was carried out on the basis of Bayesian concept of probability theory, and the criterion of decision approval - the Neyman-Pearson criteria was adapted. According to this, while determining the probability of the false choice $\left(P_{f a}=0,1 ; P_{f a}=0,01\right.$; $\left.P_{f a}=0,001 ; P_{f a}=0,0001\right)$, the probability of the correct choice was $P_{d 1}=0.8245 ; P_{d 2}=0,9733$; $P_{d 3}=0,9966 ; P_{d 4}=0,9996$ relatively.

The application of the adapted Neyman-Pearson criteria, and the determination of the probability of method selection for determining the coefficients, makes it possible to plan scientific experiments and research of the low-intensity ERS processing methods.

\section{References}

1. Environmental Health Criteria 223. Neurotoxicity Risk Asessment For Human Health: Principles And Approaches [Elektron. resurs]. Rezhym dostupu: http: www.inchem.org/documents/ehc/ehc/ehc223.htm.

2. Finkelstein D., Gouras P., Hoff M. Human electroretinogram near the absolute threshold of vision. Investigative Ophthalmology, April, 1963. Vol. 7. № 2. Pp. 214-218.

3. Hecht S. Energy, Quanta and Vision. Journal of General Physiology. July 20, 1942. Pp. 819-840. https://doi.org/10.1085/jgp.25.6.819

4. Rilk A. J. The Flicker Electroretinogram in Phase Space: Embeddings and Techniques. Aalen. 2003. 93 p.

5. Tkachuk R. A. Optymizaciya retynografichnoyi systemy dlya vyyavlennya pryhovanogo biologichnogo vplyvu na organizm lyudyny. Optyko-elektronni informacijno-energetychni texnologiyi. 2009, № 2. Pp. $145-152$.

6. Tkachuk R., Yavorskyy B. Metod pobudovy biotexnichnoyi systemy dlya ocinyuvannya elektroretynogram z pidvyshhenymy virogidnistyu ta efektyvnistyu. Visnyk TDTU. 2009. Tom 14. № 3. Pp. 102-110.

7. Tymkiv P. O., Zabytivskyj V. P., Yavorskyj B. I. Syntez filtru Kalmana dlya opracyuvannya nyzko intensyvnogo elektroretynosygnalu. Mizhnarodnyj naukovo-texnichnyj zhurnal "Vymiryuvalna ta obchyslyuvalna texnika v texnologichnyx procesax”. Hmelnyczkyj, 2016. № 1. Obmin praktychnym dosvidom ta texnologiyamy. Pp. 168-176

8. Tymkiv Pavlo. Udoskonalennya metodu opracyuvannya nyzkointensyvnogo elektroretynosygnalu: Materialy III Vseukrayinskoyi naukovo-texnichnoyi konferenciyi "Teoretychni ta prykladni aspekty radiotexniky i pryladobuduvannya", 8-9 July 2017, TNTU, 2017. Pp.123-125.

9. Tymkiv P. O. Veryfikaciya udoskonalenogo metodu vyznachennya koeficiyentiv filtru Kalmana u nyzkointensyvnij elektroretynografiy. Materialy Mizhnarodnoyi naukovo-texnichnoyi konferenciyi "Fundamentalni ta prykladni problemy suchasnyx texnologij do 100 richchya $\mathrm{z}$ dnya zasnuvannya NAN Ukrayiny ta na vshanuvannya pamyati Ivana Pulyuya (100 richchya z dnya smerti)", 22-24 May, 2018. TNTU, 2018. Pp. 22-23.

10. Shakhtaryn B. Y. Obnaruzhenye syhnalov: ucheb. Posobye. M.: Helyos ARV, 2006. 488 p.

\section{Список використаної літератури}

1. Environmental Health Criteria 223. Neurotoxicity Risk Asessment For Human Health: Principles And Approaches. URL: http://www.inchem.org/documents/ehc/ehc/ehc223.htm.

2. Finkelstein D., Gouras P., Hoff M. Human electroretinogram near the absolute threshold of vision. Investigative Ophthalmology. 1963, April. Vol. 7. № 2. Pp. 214-218.

3. Hecht S. Energy, Quanta and Vision. Journal of General Physiology. 1942. July 20. Pp. 819-840. https://doi.org/10.1085/jgp.25.6.819

4. Rilk A. J. The Flicker Electroretinogram in Phase Space: Embeddings and Techniques. Aalen. 2003. 93 p.

5. Ткачук Р. А. Оптимізація ретинографічної системи для виявлення прихованого біологічного впливу на організм людини. Оптико-електронні інформаційно-енергетичні технології. 2009. № 2. C. $145-152$.

6. Ткачук Р., Яворський Б. Метод побудови біотехнічної системи для оцінювання електроретинограм 3 підвищеними вірогідністю та ефективністю. Вісник ТДТУ. 2009. Том 14. № 3. С. 102-110.

7. Тимків П. О., Забитівський В. П., Яворський Б. І. Синтез фільтру Калмана для опрацювання низькоінтенсивного електроретиносигналу. Міжнародний науково-технічний журнал «Вимірювальна та обчислювальна техніка в технологічних процесах». Хмельницький 2016. № 1. C. $168-176$ 
8. Тимків Павло. Удосконалення методу опрацювання низькоінтенсивного електроретиносигналу: матеріали III Всеукраїнської науково-технічної конференції «Теоретичні та прикладні аспекти радіотехніки і приладобудування» (8-9 червня 2017 року). ТНТУ, 2017. С. 123-125.

9. Тимків П. О. Верифікація удосконаленого методу визначення коефіцієнтів фільтру Калмана у низькоінтенсивній електроретинографії: матеріали Міжнародної науково-технічної конференції «Фундаментальні та прикладні проблеми сучасних технологій до 100-річчя 3 дня заснування НАН України та на вшанування пам'яті Івана Пулюя (100-річчя 3 дня смерті)» (22-24 травня 2018). ТНТУ, 2018. С. 22-23.

10. Шахтарин Б. И. Обнаружение сигналов: учеб. пособие. М.: Гелиос АРВ, 2006. 488 с.

\title{
УДК 53.05: 617.753
}

\section{АДАПТАЦІЯ КРИТЕРІЮ НЕЙМАНА-ПІРСОНА ДЛЯ ОЦІНЮВАННЯ ДОСТОВІРНОСТІ ВИБОРУ МЕТОДУ ВИЗНАЧЕННЯ КОЕФІЦІЕНТІВ МАТЕМАТИЧНОЇ МОДЕЛІ НИЗЬКОІНТЕНСИВНОГО ЕЛЕКТРОРЕТИНОСИГНАЛУ}

\author{
Павло Тимків
}

\author{
Тернопільський нащіональний технічний університет імені Івана Пулюя, \\ Тернопіль, Україна
}

\begin{abstract}
Резюме. При зменшенні інтенсивності світлового подразнення для виявлення ризиків нейротоксикачії, отримують низькоінтенсивний електроретиносигнал, який необхідно додатково опрацьовувати. Це виникає внаслідок малого відношення енергії корисного сигналу до енергії шуму, невідомої природи иумів (иумів біоб'єкта, від електродів чи підсилювачів) та зміни форми електроретиносигналу чи його складових (хвиль) внаслідок невідомого впливу нейротоксикації. В роботах Ткачука Р. А. та Яворського Б. І. запропоновано застосування фільтра Калмана і методу визначення коефіцієнтів математичної моделі електроретиносигналу. Проте використаний метод прямого направленого перебору (пошуку) коефіцієнтів, має значну часову складність, щзо унеможливлює автоматизоване застосування цे переналаштування фільтра Калмана для опраџювання низькоінтенсивного електроретиносигналу. Відомі роботи, в яких проведено удосконалення методу визначення коефіцієнтів математичної моделі низькоінтенсивного електроретиносигналу шляхом перебору у кілька ітерацій зі зміною кроку перебору. Тому для оцінювання запропонованого удосконаленого методу необхідно провести статистичне випробовування вибору методу-прототипу та удосконаленого методу й визначити достовірності результатів вибору. Завдання вибору методу визначення коефіцієнтів математичної моделі низькоінтенсивного ЕРС вирішується методами статистичної теорії вибору рімень. Оцінювання достовірності проведено на базі байєсівської концепиії теорії ймовірності, на підставі вибрано критерій Неймана-Пірсона та адаптовано його до задачі вибору (затвердження) рімення. Для изього проведено імітащійне моделювання ансамблю низькоінтенсивних ЕРС при використанні методу-прототипу та удосконаленого методу, й визначено середньоквадратичну похибку моделювання кожного з методів як міру вибору. Достовірність вибору методу пошуку коефіцієнтів визначалася при фіксованій імовірності помилкового вибору методу (0,1;0,01;0,001 та 0,0001).
\end{abstract}

Ключові слова: електроретинографія, електроретиносигнал, математична модель, низькоінтенсивний електроретиносигнал, фільтр Калмана, критерій Неймана-Пірсона. 